Robertson, P.J. (2017). Positive psychology and career development. British Journal of Guidance and Counselling [forthcoming].

This is a pre-publication version of this article, accepted for publication but prior to copy editing. If possible please access the final published version. 


\title{
Positive Psychology and Career Development
}

Peter J. Robertson

Edinburgh Napier University

Edinburgh Napier University,

School of Applied Sciences,

Sighthill Campus,

Edinburgh EH11 4BN.

p.robertson@napier.ac.uk

\begin{abstract}
Positive psychology has been an influential movement within psychology in the early years of the 21 st century. It is now timely to assess the value of its contribution to career education and guidance. This paper provides a critique of this perspective. Positive psychology can enrich approaches to career development. It can provide a fertile source of concepts and an empirical basis for some elements of practice. However the application of approaches derived from positive psychology is problematic if it neglects the socio-economic context in which careers are lived and experienced, or if claims are made for its efficacy cannot be supported by the evidence base.
\end{abstract}

Key words: Career development; positive psychology; well-being

\section{Introduction}

Positive psychology is best understood not as a sub-discipline or specialism, but rather as a movement to change the nature of psychology. It aims to rebalance the discipline by counteracting the bias towards pathology and dysfunction (Seligman \& Csikszentmihalyi, 2000). Psychology's focus on negative experience certainly applies in the employment domain: stress persists as a major preoccupation in work psychology (e.g. Graham, Howard \& Dougall, 2012). Positive psychology brings to the table a focus on healthy functioning, positive experiences and well-being. Linley, Harrington \& Garcea (2010) call for a move away from a deficit approach to problem solving at work towards an 'abundance approach' that highlights human potential. Rath \& Harter (2010) take the link between positive experiences and working lives a step further. Drawing on extensive survey research by the 
Gallup organisation, they identified career as one of five key elements to well-being (along with social, financial, physical and community well-being). Locating career experiences as central to building a good life is a position that career scholars might find appealing. There is also reason to believe that positive experience at work has wider health benefits. Persuasive evidence indicates a positive relationship between job satisfaction, and more global measures of life satisfaction and health (Erdogan, Bauer, Truxillo \& Mansfield, 2012; Faragher, Cass \& Cooper, 2005).

A key feature of the positive psychology movement is that its focus on promoting positive well-being is of relevance to the whole population. Counselling applications derived from it lend themselves to non-clinical settings, and now form one of the key conceptual underpinnings to coaching psychology practice (e.g. Boniwell, Kaufmann \& Silberman, 2014; Linley \& Harrington, 2007). Thus techniques derived from positive psychology may be a comfortable cultural fit with career counselling or coaching. The focus is on promoting effective functioning; not on the management of symptoms or distress. This has encouraged some, notably Jacobsen (2010) and Yates (2013a) to explore the value of applying positive psychology to career counselling.

This paper will further explore this area. First selected contributions of positive psychology to career development will be highlighted, then limitations and weaknesses of the movement will be outlined, with a view to finally providing a balanced assessment of its contribution to career guidance and development.

\section{Contributions from Positive Psychology}

This section will highlight some of the important themes emerging from positive psychology that provide insights of potential value to career development practice and research.

\section{Concepts of well-being: hedonia and eudaimonia}

Positive psychologists make distinctions between different kinds of well-being. The dichotomy between hedonia and eudaimonia (e.g. Deci \& Ryan, 2008; Ryff \& Singer, 2008) is a useful distinction when considering well-being at work (Straume \& Vitters $\varnothing, 2012$ ).

Hedonia relates to happiness in the sense of positive mood and pleasure, but it is eudaimonia that is more obviously relevant to the study of careers. Eudaimonia encompasses ideas such 
as engaging in purposeful or pro-social activity, fulfilling one's true nature, and effective functioning. Whilst hedonic experiences may come and go, eudaimonia suggests a focus on lifestyles that promote a more sustainable kind of well-being and a meaningful life (Ryan, Huta \& Deci, 2008). Work seems unlikely to provide passive hedonic pleasure; access to absorbing activities, healthy relationships and opportunities for personal growth seems more plausible. So career development might be understood as an activity with eudaimonic wellbeing as its ultimate goal.

It would be premature to discard hedonic well-being entirely. It is the focus of Fredrickson's (2005) 'broaden and build' theory of positive emotion. This perspective does not see positive emotion as an end in itself. Rather sees it positive emotion as promoting playful exploration, which in turn leads to a virtuous circle of learning and growth, leading to long term benefits including more positive emotion (Boniwell, Kaufman \& Silberman, 2014). The broaden and build theory is now well supported by empirical evidence (Garland et al 2010), which indicates that positive emotions have short term effects on broadening thinking and attention, and longer term effects in building personal coping resources and positive feelings. Frederickson's approach to the 'seeding' of positivity is advocated by Jacobsen (2010) for use in career counselling. Whilst early approaches to vocational guidance placed clients in a passive role, many contemporary perspectives on career learning advocate promotion of proactive behaviour and research (e.g. Krumboltz, 1996; McCash, 2006; Taviera \& Moreno, 2003). Arguably these activities are facilitated by an open and positive state of mind. Indeed the 'Planned Happenstance' approach to career counselling (Mitchell, Levin \& Krumboltz, 1999) recommends encouraging curiosity and even playful exploration in clients. Thus Frederickson's thinking may help to provide a starting point for understanding the necessary emotional pre-conditions for career exploration to be effective.

\section{Flow and interests}

Csikszentmihalyi's (2002) concept of 'flow' is of direct relevance to careers. Flow is related to the more familiar concept of interests (e.g. Closs, 1993), but it is more specific, referring to the state of being completely absorbed in an activity. This experience is often associated with losing both a sense of self, and a sense of the passage of time. Flow experiences are a kind of transient well-being, but more importantly can have a positive influence on the rest of the life-space. Flow experiences are more common at work rather than home, because the 
environment provides clear goals, challenges, and demands concentration (Seligman, 2002). Dik and Hanson (2008) provide an in-depth exploration of the link between interests, careers and well-being. They argue that transient emotional experiences of interest can grow into an enduring disposition that underpins meaningful work and facilitates eudaimonic well-being. Vocational interests are well established focus for career counselling, and continue to be taken seriously as a topic of study (e.g. Savickas \& Spokane, 1999; Silvia, 2006; Dik \& Hansen, 2008). Interest inventories have advantages over other kinds of assessment tools (such as cognitive ability, personality, or learning styles) as they relate so directly to occupational choice. The links established by positive psychologists between flow and wellbeing can only strengthen confidence in the use of interests as a central concept in careers work. Further support comes from Henderson's (2000) small scale qualitative study of individuals selected for their strong career happiness. These individuals displayed an enduring commitment to follow their interests: those areas that they succeeded in and enjoyed.

\section{Meaning in careers and the concept of a 'calling'}

Some positive psychologists have gone some way beyond a focus on interests by suggesting people should pursue a 'calling' in life, using a religious metaphor for occupational choice and persistence in a line of work (e.g. Steger \& Dik, 2009; Harzer \& Ruch, 2012). This concept is a recurring theme in applications of positive psychology to work (Mills, Fleck \& Kozikowski, 2013). The work of Wrzesniewski (e.g. 2003; 2012) seems to have been influential in the field. Calling relates to a eudaimonic conception of well-being. There are problems of definition here (Hirschi, 2011), for example a calling may require an external quasi-spiritual summons or alternatively may arise from internal reflection. Another issue is whether calling necessarily means an altruistic and pro-social career path. Acknowledging diversity in definitions and approaches to measurement, Dik \& Duffy (2013) summarise research in the field, and report evidence for a relationship between having a calling and life satisfaction, an important well-being variable.

Explorations of calling are one facet of a wider trend in positive psychology to explore meaning in work (e.g. Steger \& Dik, 2010; Schnell, Höge \& Pollett, 2013). Dik et al (2015) point out the value of a systematic and explicit focus on meaning as an important concept which is implicit throughout theories of vocational choice and career development. Dik, 
Duffy \& Eldridge (2009) recommend career counsellors assess the relevance of calling to individuals, promote an active approach to seeking meaning at work, and incorporate a spiritual dimension to their guidance.

\section{Career success}

The study of career success represents one lens through which to view the relationship between positive experiences and careers. A useful distinction can be made between objective and subjective career success (e.g. Poole, Langan-Fox and Omodei, 1993; Ng, Eby, Sorensen \& Feldman, 2005; Abele\& Spurk, 2009). In this context, objective success refers to indicators such as pay and hierarchical status, whereas subjective success refers to an individual's evaluation of their own career, and it is the latter that is of most interest here. One interesting finding to emerge in this field suggests that rather than happiness being a consequence of career success, in fact the reverse may be true. At least to some extent happiness precedes and facilitates success in the work context. A review of 225 sources exploring the links between success and happiness, found that happiness often led to successful outcomes rather than following on from them (Lyubomirsky, King \& Diener, 2005). Similarly, Boehm \& Lyubomirsky (2008) reviewed cross-sectional, longitudinal and experimental evidence on the effects of positive affect on a variety of work related variables. They concluded that happiness is not just associated with career success but it also precedes success and positive work outcomes. Some support for this position comes from a metaanalysis of the relationship between job satisfaction and subjective well-being by Bowling, Eschleman \& Wang (2010). In addition to identifying a relationship they found that longitudinal studies indicated that subjective well-being was stronger determinant of job satisfaction than vice versa. This evidence is both counter-intuitive and valuable, as it suggests career related benefits may follow from broader based happiness interventions. There are strong parallels with Fredrickson's (2005) 'broaden and build' theory here. Jacobsen (2010) suggests that when clients come to career counsellors seeking the right job to make them happy, they have got it back to front. She claims that approaches to promote positive well-being can be used in career counselling and will in the long run tend to promote career success. A longitudinal study in both USA and Germany by Haase, Poulin \& Heckhausen (2012) provides relevant evidence. They found that striving for career and educational goals was predicted by positive affect. 


\section{Strengths}

There are reasons to believe that character strengths are relevant to career development. For example, Littman-Ovadia \& Davidovitch (2010) found that the deployment of strengths was related to personal well-being and job satisfaction, and was complementary to congruence between academic studies and choice of occupation. Lopez, Snyder \& Rasmussen (2003) suggest there is a need to strike a balance between the assessment of human weaknesses and strengths. They argue the assessment of positive characteristics has applications in counselling and rehabilitation psychology. They stress that strengths are as real as weaknesses although they have received less attention. Snyder et al. (2003) take this argument a stage further by suggestion that the act of naming and labelling a positive characteristic (and subsequently measuring it) in itself sends a powerful message to a service user that it is something of importance.

Thus positive assessment tools may bring something distinctive to a career education and guidance setting. These include 'StrengthsQuest' (Clifton, Anderson \& Schreiner, 2006), which focuses on identifying and building on talents and abilities. The most influential tool is the 'Values in Action Institute Inventory of Strengths' (VAI-IS: Peterson \& Seligman, 2004), a character strength assessment with evidence of rigorous psychometric development (Park \& Peterson, 2007). It represents an attempt to answer Seligman's call to identify what is right with people, in contrast to the clinician's preoccupation with diagnosing what is wrong with them. In this model, character strengths are classified into six main groups: wisdom and knowledge; courage; humanity; justice; temperance; and transcendence. Each of these is further subdivided into between three and five character strengths (e.g. justice subdivides into fairness, leadership, and teamwork). Some strengths may have more generic value in the workplace, for example Littman-Ovadia \& Lavy (2016) identify perseverance as a key indicator of work performance, and likely to be necessary to sustain successful careers in the long term. In common with occupational interest inventories, strength assessments are unthreatening to feedback, an appealing feature in tools used for development purposes.

The focus on positive strengths may boost self-esteem, whilst reducing resistance to change, and motivating action. Strengths assessments cannot offer precise occupational recommendations, but career choices will tend to involve capitalising on available strengths 
and resources (Klimka \& Budzińska, 2015; Yates, 2013b). Once their 'signature strengths' are identified, clients can be encouraged to practice using them and to seek novel situations and ways to deploy them. Dik et al (2015) claim that the development of strengths promotes well-being in the work context, and is associated with experiencing work as meaningful. In the UK, Linley \& Harrington (2006; 2007) have been involved in adapting these assessments for workplace application.

Littman-Ovadia, Lazar-Butbul \& Benjamin (2014) developed a protocol for strengths based career counselling and tested it in comparison to a more standard career counselling approach with an unemployed group. They found the strengths based intervention produced better selfesteem outcomes, and satisfaction with the counselling process. Owens, Moti \& Krieshok (2015) were more equivocal. Working with college students, they compared the effectiveness of careers intervention based around interest assessment with an intervention based around strengths assessment, and with both in combination. The combined approach produced the best results across a range of outcomes including career decision making selfefficacy, but only marginal benefits above the interest based intervention.

\section{Career interventions and outcomes}

Magyar-Moe, Owens \& Scheel (2015) suggest that the counselling literature embraces the practice of developing strengths rather more readily than the empiricism that underpins it. Thus a distinction might need to be drawn between interventions inspired by applications of positive psychology, and the use of positive outcomes in research and evaluation studies. A good example of the former is provided by Zikic \& Franklin (2010) who describe a holistic career counselling framework that is inspired by constructivism and positive psychology. Narrative approaches are used to focus on valued experiences, so as to generate positive affect and identify strengths. Whilst no rigorous evidence of effectiveness is presented, this illustrates how positive psychology can inspire holistic and hybrid approaches to innovative career counselling practice.

There is evidence for the effectiveness of positive counselling or coaching techniques, but it is not unambiguously persuasive. Mongrain \& Anselmo-Matthews (2012) replicated an influential study by Seligman et al. (2005) examining the effectiveness of two techniques: 'Three good things' (a gratitude activity); and 'Using your signature strengths in a new way'. 
They found some enduring improvements in happiness but more modest effect sizes than the original study, and by improving the control group conditions, they were able to demonstrate the techniques had no specific therapeutic efficacy beyond encouraging positive self-relevant information.

Robertson (2013) explored the use of well-being as an outcome of interest in career guidance research, and made a case for its potential value. Preskill \& Donaldson (2008) provide a good example of how drawing on ideas from positive psychology can inform the challenging and often neglected task of evaluating career development. From a human resources management (HRM) perspective, they outline an innovative approach to evaluating a career development intervention. They used 'appreciative inquiry', a participative organisational research method, which pre-dates the positive psychology movement but now incorporates strengths based approaches (e.g. Cooperrider, Whitney \& Stavros, 2008). With this approach they were able to assess the effectiveness of a mentoring programme for women.

Another example relates not just to a different context but also a very different approach. Peng (2015) successfully used a strengths based career education programme 'infused' with spirituality to reduce state anxiety in Taiwanese students. Acknowledging the links between life-design and resilience in contemporary career thinking, Peng sees career counselling as a way to combat contemporary stresses faced by students.

\section{Limitations and weaknesses}

Positively psychology has attracted critics, and their contributions have met with rebuttals from its advocates. This section introduces the main criticisms, drawing extensively on the work of Davies (2015), Ehrenreich (2009), Fineman (2006), Hackman (2009), Held (2004), Lazarus (2003), Magyar-Moe, Owens \& Conoley (2015), Power (2016), Schneider (2011), van Deurzen (2009), and Warren (2010). There is considerable overlap in the objections they raise, so the aim here is to integrate and summarise this material, while contextualising the critique to the career development field.

\section{Old wine in new bottles}

The study of healthy functioning pre-dates the positive psychology movement. This is evident in the humanistic psychology of the mid-20 th century (e.g. Maslow, 1970). This is perhaps the least persuasive of the criticisms as positive psychologists are explicit about the 
earlier traditions that they build on. Joseph (2015) highlights the synergy between positive psychology and person centred psychotherapy derived from the work of Carl Rogers. For him the promotion of effective functioning, going beyond dealing with dysfunction, was always the core purpose of counselling. The counsellor attitudes and skills derived from person centred approaches are a foundation for career guidance, and many other counselling applications. More generally, some UK counselling psychologists have recently argued that positive psychology can help their profession resist the encroachment of a medical model on their practice, and reconnect with their original project to promote human flourishing, and positive well-being. Such a development might bring coaching psychology, counselling psychology and career counselling closer together, in a way consistent with the shared historical roots and values of these practices (Grant \& Palmer, 2015; Robertson, 2015; Steffen, Vossler \& Joseph, 2015).

In spite of a relative neglect of an explicit focus on subjective well-being in career theory and practice, positive psychology appears to have great resonance with the pre-existing career development literature. Eggerth (2008), Juntunen \& Wettersten (2006), Robitscheck \& Woodson (2006) all point to the synergy between vocational psychology and positive psychology, in the shared focus on promoting effective functioning in the work and education domains. Savickas (2008) in particular, has argued that vocational psychology was already promoting positive functioning before the arrival of positive psychology. Hartung \& Taber (2008) point to the substantial literature on work adjustment and job satisfaction, representing a wealth of evidence related to the promotion of positive health and well-being.

\section{Positive psychology as 'positive thinking'}

Positive psychology has been accused of naïve 'Pollyanna' positivity, a view that is rejected by its advocates (Diener, 2003). Whilst positive psychologists seek to distance their evidence based work from earlier populist notions of positive thinking (e.g. Peterson, 2009), they routinely present happiness as an attainable goal, and by implication as a reasonable expectation. But happiness as an emotion is fleeting and not readily captured. Kidd (1998), in her discussion of the neglect of emotion in the study of career, acknowledges its transient nature.

The valorisation of happiness in positive psychology implies that the negative emotions must be avoided. The critics argue that bad feelings have important adaptive functions, and are 
essential to a healthy personality. Negative emotions can lead to positive outcomes (Norem $\&$ Chang, 2002). For example anxiety or pessimism can provoke prudent caution. Conversely positive emotions may sometimes be dysfunctional, as in the case of excessive optimism leading to risky or delusional behaviour. Emotions occur within a context, and relentless cheerfulness may be neither appropriate nor desirable in a well-integrated adult. A related issue is the political function of negative emotion: it can lead to demands for social and economic reform (such as industrial action) and this may be better in the long run than a psychological palliative.

\section{Positive psychology as healing}

Whilst decrying the preoccupation with human deficits, the positive psychology movement subtly reinforces it. It has been quick to embed itself within not just counselling, but also the popular self-help and self-improvement literature. In urging people to experience positive emotions, it implies that we are sub-optimal beings if we fail to do so. The absence of happiness becomes a deficit that requires a 'fix'. If the remedy fails, then individuals must look to their own failure to follow the guidelines assiduously enough. It also locates positive psychology within a well-established 'happiness industry', with products to sell.

Positive psychology is viewed by some critics as part of a wider social trend towards emotional demonstrativeness, confessional self-disclosure, and a therapeutic colonisation of everyday life (e.g. Ecclestone \& Hayes, 2008). Positive psychologists (e.g. Seligman \& Csikszentmihalyi, 2000) have been at pains to distance themselves from the individualism and narcissism of the self-help movement, and point to their evidence base as a key distinguishing feature.

\section{Positive psychology as a capitalist project}

There is another way in which the movement is commercial in its nature, and one that becomes apparent in 'positive organisational scholarship', a label recently attached to workplace applications of positive psychology. This literature is preoccupied with improving worker productivity. Worker well-being is a concern, but a secondary one, assumed to be in a win-win correlation with productivity (e.g. Harter, Schmidt \& Keyes, 2002; Diener et al., 2009). Independent reviews of the evidence linking well-being related variables to productivity tend to be more cautious and equivocal (e.g. Cropanza \& Wright, 2001; Shackleton, 2012). Positive organisational scholarship seems to be primarily for the benefit of 
the employer. The literature ignores potential conflict of interest between different actors in the labour market. It identifies the worker's positive emotions as a motivational resource to be activated and deployed. In the light of this perspective, notions such as 'calling' become problematic, because a radical critique might suggest that persuading an employee that their mundane work has a higher meaning is potentially a way of extracting greater labour for no greater cost. This is described as the 'dark side' of calling by Duffy \& Dik (2013). It resonates with a wider movement towards the commercial use of employee feelings, best illustrated by Hochschild's (1983) influential book, 'The managed heart: the commercialisation of human feeling', in which the notion of emotional labour is outlined.

\section{Positive psychology as an ethno-centric cultural movement}

All movements need to be understood in terms of their cultural roots. Positive psychology emerged in the USA at the end of the $20^{\text {th }}$ century. More than an academic activity within one discipline, it is a wider cultural movement. It is not value neutral (Cameron, Dutton \& Quinn, 2003). An evangelical style is evident in the popular positive psychology texts (e.g. Seligman, 2002). Seligman (2002) proposes that positive psychology needs to link to spirituality. As Harris, Thoresen \& Lopez (2007) point out, there are complexities in drawing religious and spirituality in positive counselling. Sheldon \& Lyubomirsky present empirical evidence that hard work is the best route to achieving sustainable happiness, something they describe as “...consistent with the Puritan version of the American dream" (2006, p 82, their italics). Indeed, the 'pursuit of happiness' is explicit in the Declaration of Independence (Jefferson, 1776). Relatively more sceptical and secular European audiences may be cautious about adopting a world view rooted in American social, economic, spiritual and cultural assumptions. This argument must not be overstated as it could represent a negative stereotypical caricature. It is important to note that some positive psychologists, notably Biswas-Diener (e.g. 2006), have sought to address these concerns by developing an international and multi-cultural empirical evidence base.

\section{Positive psychology and unemployment}

The unemployed are potentially exposed to greater threats to their mental well-being than those in work (Waddell \& Burton, 2006). The economist Lord Layard has been a leading advocate of the importance of the public mental health perspective that positive psychologists have highlighted (e.g. Layard, 2005). Recognising both the costs to society and individual 
distress associated with unemployment, he was influential in encouraging the adoption of evidence based psycho-therapeutic interventions in welfare-to-work settings in the UK. However well intentioned, the resulting attempts to 'fix' unemployed people's emotions while leaving their socio-economic situation unchanged has attracted fierce criticism, for example:

The context in which positive psychology's motivational techniques are deployed, then, is one structured by a regime of tacit and explicit threat and coercion, in which one can never be sure whether or not a sanction will be tagged to a particular instance of behaviour or attitude. As many first-hand accounts witness, Jobcentres and the premises of welfare-to-work contractors are not neutral settings for interventions or decisions about the relative degree of unemployed people's material hardship, 'willingness to work', 'readiness' for work or 'resistance' to work: they are intensely anxiety-inducing and intimidating locations that bear witness to marked imbalances of power.

(Friedli \& Stearn, 2015, p45).

This illustrates the potential difficulty in translating psychological interventions that are intended to be empowering into contexts where political and economic factors can distort their noble goals. In practice the techniques used in such settings are often derived from other psychological traditions, notably cognitive-behavioural therapy (CBT) (e.g. Proudfoot, Guest, Carson, Dunn \& Gray, 1997; Kellett, Purdie, Bickerstaffe, Hopper, \& Scott, 2013). Nonetheless, the underpinning rationale used by Layard (2005) and described in the example above is clearly rooted in positive psychology. By making access to welfare benefits conditional on participation in quasi-therapeutic activities, the meaning of these interventions is fundamentally changed. Whilst intended to ameliorate the psychological detriments experienced by the unemployed, they risk the perverse consequence of reinforcing a coercive labour activation agenda.

\section{Constructs and approaches to measurement}

Positive psychology is firmly rooted in mainstream empirical psychology and has rapidly amassed a large evidence base, and this foundation is central to its credibility. Mills, Fleck \& Kozikowski (2013) in their review of positive organisational scholarship, described this emerging literature as fragmented. They provide a review of constructs used, which include resilience, empowerment, gratitude, psychological capital, employee engagement, perceived support, positive teamwork, and positive leadership. To this we can add key happiness constructs such as positive affect and life satisfaction (Diener, 1984). These can be global 
measures or more domain specific e.g. job satisfaction (Warr, 2007). This list is by no means exhaustive. Recent interest in career adaptability indicates another construct linked to optimism (Rottinghaus, Day \& Borgen, 2005) and to well-being (Maggiori et al., 2013). Work hope represents yet another example (Juntunen \& Wettersten, 2006). Arguably, there too many happiness and well-being related constructs used in positive psychology, with insufficient attention to their construct validity and extent of overlap between them (Hackman, 2009).

The tendency to rely on single self-report bipolar scales for measurement of affect is not unproblematic (Isen \& Erez, 2007). This may make sense at a population level where information must be discarded, but risks gross oversimplification at a local or individual level, where feelings may be a complex mix of positive and negative emotion and are inseparable from their meaning. People have reasons for being happy or unhappy that make sense only when understood in context. There have been attempts to apply psychometric approaches to meaning at work and in careers (e.g. Steger, Dik \& Duffy, 2012). Whilst acknowledging the value of quantitative methods, this field seems to suffer from a relative neglect of qualitative research methods, which are ideally suited to explore meaning. Bimrose \& Hearne's (2012) qualitative study of resilience, provides an exemplar of its potential contribution.

A more general concern relates to the nature of psychological measures of happiness and well-being. The economist and philosopher Sen (e.g. 1987) has questioned the exclusive reliance on subjective measures in an attempt to capture how people's lives are going, with the observation that people accommodate themselves to their circumstances. A person living in poverty may report feeling happy in far from satisfactory living conditions (BiswasDiener, 2008). Their judgments are constrained by the breadth of their horizons, their expectations, and the availability of benchmarks for comparison. Subjective psychological assessments of well-being, if used in isolation, could be considered an inadequate measure of quality of life if people habituate to deprivation (Binder, 2013).

Careers unfold over time in employment, educational and community settings, and thus demand longitudinal study. To date the positive psychology research effort has been overreliant on workplace focused cross-sectional research. This is not unique to the movement; a similar critique could be made of much research in work psychology. 


\section{Individual differences}

Applications of positive psychology to work are often infused with a differentialist perspective (e.g. Bono, Davies \& Rasch, 2012; McGregor, McAdams \& Little, 2006). Through this lens, it is desirable to encourage an individual to find a role in which they are both productive and achieve job satisfaction. Thus both employee and employer would be content, and a stable employment situation would be achieved. This is an attractive notion, and it has resonance with the long-established trait and factor tradition in career development (e.g. Rodgers, 1952 ; Holland, 1997) and its more recent manifestations as personenvironment fit theory (e.g. Dawis \& Lofquist, 1994).

There are reasons for caution here. Firstly, the trait and factor tradition is the most robustly criticised conception of career development for reasons including the unsafe assumption of a static nature of people and of work, treatment of career choice as an event rather than a process, and neglect of contextual social factors (e.g. Bimrose, 2009). Secondly, positive well-being may be, at least in part, a trait rather than just a state: individual differences in personality, such as neuroticism, are an important driver of well-being. Thirdly, as Warr (2007) has very persuasively demonstrated, some jobs are simply better than others, because they provide access to the psycho-social factors that promote happiness and well-being; indeed the importance of quality of work is an issue enjoying a revival of interest in the wider social sciences (Findlay, Kalleberg \& Warhurst, 2013).

\section{Over-interpretation of the evidence base}

Nettle (2006) suggests that positive psychologists, particularly in their popular texts, slip into prescriptive writing about how people ought to live based on moral judgments of what a good life looks like. The problem is that these prescriptions are not necessarily sustained by the evidence, and may represent unsafe extrapolations. In the context of career coaching, some sources (e.g. Biswas-Diener \& Dean, 2007) confidently recommend that career coaches support their clients to find a calling. These prescriptions draw heavily on Wrzesniewski's $(2003 ; 2012)$ threefold distinction between a job (for money), a career (for status advancement) and a calling (which by implication is a superior way). This represents a simplistic view of the dynamic relationship people have to their work and careers as they unfold over time. It is also an unrealistic prescription for those who choices are greatly constrained by social, educational, economic, geographic or health factors. It is appropriate 
primarily to middle class populations, a criticism also applicable to the wider career counselling literature (e.g. Blustein, 2011). Duffy \& Dik (2013) acknowledge that calling may be relevant to only a third of clients.

\section{Conclusion}

Views of the advocates and critics of positive psychology could hardly be more polarised. It presents a challenge to reconcile them, but that is the task here, so as to present a balanced view to career development practitioners. There is a sense in which criticising positive psychology for being too positive, too psychological, and too capitalist is a bit like blaming a giraffe for having a long neck. It bears the stamp of the culture that it sprang from, and adopts the methods and level of analysis of its parent discipline. It does not provide a coherent overarching theory of careers and career development; but it did not set out to do that. Whilst some of its preoccupations are neither new to psychology, nor new to the study of career development, this is not important.

Positive psychology offers a seductive promise of virtuous circles, with rigorous scientific methods to back it up; but it remains a problematic offer. There are two substantive concerns about the contribution of positive psychology to career development. Firstly, it neglects the power of the socio-economic contexts within which the lived experience of careers are acted out. Indeed it has embedded cultural values which could potentially serve to reinforce and reproduce unequal structures in society, if its applications are not highly sensitive to their socio-political context. Secondly, the enthusiasm of its advocates has led to prescriptions for life and career that go some considerable way beyond a safe interpretation of its evidence base. In the very specific case of applications to career development interventions, the evidence base is limited, and most contributions to the literature are proposals based on extrapolating from theory or from applications in other contexts. The effectiveness of its recommended techniques when applied in career development contexts remains largely untested (e.g. Dik, Duffy \& Eldridge 2009). Whilst it may be tempting, particularly in private practice, to attract clients with promises of 'career happiness', there is not (or not yet) a sound basis for such claims.

Nonetheless career development practitioners may find in this extensive literature some valuable things to take away. It represents a fertile source of innovative approaches to career counselling, such as the identification of strengths, and the promotion of positive feelings and 
positive orientations to the future. Positive psychology has generated assessment tools, which may provoke useful reflective discussion with a client, and are likely to be benign provided their use is consensual and sensitive to the context. The systematic study of positive experiences has facilitated the use of well-being as an outcome variable of interest in career research. When working with individuals however, the personal contextual meaning of career experiences should not be neglected in favour of the measurement of simple single scale, bipolar constructs.

The prognosis for positive psychology may be that, like many movements, it will run its course and will merge back into mainstream psychology. Alternatively, the recent emergence of a 'second wave' of positive psychology may addresses some key criticisms, specifically the importance of a healthy balance of negative and positive emotion (Ivtzan, Lomas, Hefferon \& Worth, 2015; Lomas, 2016). Research efforts in some of the fields discussed in this paper are currently very dynamic, notably in relation to calling and meaning at work. A recent awakening of interest in qualitative research is evident in the Journal of Positive Psychology (e.g. Grant, 2016). We might expect these trends to continue to generate valuable material for some time to come.

Positive psychology may enrich a technically eclectic approach to career development and provide a fruitful focus on well-being, but it is not well placed to provide a comprehensive, integrative and ethical foundation for practice. 


\section{References}

Abele, A.E. \& Spurk, D. (2009). How do objective and subjective career success interrelate over time? Journal of Occupational and Organizational Psychology, 82, 4, 803-824. doi: 10.1348/096317909X470924

Bimrose, J. (2009). Matching theories (trait/factor). Warwick: Institute of Employment Research/National Guidance Research Forum. [Online] Available from: http://www.guidanceresearch.org/EG/impprac/ImpP2/traditional/matching.

Bimrose, J. \& Hearne, L. (2012). Resilience and career adaptability: Qualitative studies of adult career counselling. Journal of Vocational Behavior, 81, 338-344. doi: 10.1016/j.jvb.2012.08.002

Binder, M. (2013). Subjective Well-being Capabilities: Bridging the Gap between the Capability Approach and Subjective Well-Being Research (Papers on Evolution and Economics \#1302). Jena: Max Plank Institute.

Biswas-Diener, R. (2006). From the equator to the North Pole: A study of character strengths. Journal of happiness studies, 7, 293-310.

Biswas-Diener, R. (2008). Material wealth and subjective well being. In: M. Eid. \& R.J. Larsen, (Eds.) The science of subjective well being. New York: Guilford Press. pp307-322.

Biswas-Diener, R. \& Dean, B. (2007). Positive psychology coaching: Putting the science of happiness to work for your clients. Hoboken, NJ: John Wiley.

Blustein, D.L. (2011). Vocational Psychology at the Fork in the Road: Staying the Course or Taking the Road Less Traveled Journal of Career Assessment, 19, 3, 316-322.

Boehm, J. K., \& Lyubomirsky, S. (2008). Does happiness promote career success? Journal of Career Assessment, 16, 101-116. doi:10.1177/1069072707308140

Boniwell, I, Kaufman, C. \& Silberman, J. (2014). The positive psychology approach to coaching. In S.Cox, T.Bachkirova \& D. Clutterbuck (Eds.). The complete handbook of coaching (2nd edition, pp.157-169), London: Sage.

Bono, J.E., Davies, S.E. \& Rasch, R.L. (2012). Some traits associated with flourishing at work. In: K.S.Cameron \& G.M. Spreitzer (Eds) The Oxford handbook of positive organisational scholarship. pp. 125-137. Oxford: Oxford University Press.

Bowling, N.A., Eschleman, K.J. \& Wang, Q. (2010). A meta-analytic examination of the relationship between job satisfaction and subjective well-being. Journal of Occupational and Organizational Psychology, 83, 915-934. doi:10.1348/096317909X478557

Cameron, K.S, Dutton, J.E. \& Quinn, R.E.(2003). Foundations of positive organisational scholarship In K.S. Cameron, J.E. Dutton \& R.E. Quinn (Eds.) Positive organizational scholarship (pp.3-13) San Francisco: Barrett-Koehler.

Clifton, D.O., Anderson, E.C. \& Schreiner, L.A. (2006). StrengthsQuest: Discover and develop your strengths in academics, career, and beyond. New York: Gallup Press.

Clifton, D.O. \& Harter, J.K. (2003). Investing in strengths. In K.S. Cameron, J.E. Dutton \& R.E. Quinn (Eds.) Positive organisational scholarship, pp111-121, San Franciso: Berrett-Keohler.

Closs.S.J. (1993). The JIIG-CAL reference manual London: Hodder \& Staughton. 
Cooperrider, D.L., Whitney, D. \& Stavros, J.M. (2008). Appreciative Inquiry handbook: For leaders of change. ( $2^{\text {nd }}$ edition). Oakland, CA: Berrett-Koehler.

Cropanza, R. \& Wright, T.A. (2001). When a "happy" worker is really a "productive" worker: a review and further refinement of the happy-productive worker thesis. Consulting Psychology Journal: Practice and Research, 53, 3, pp. 182-199.

Csikszentmihalyi, M. (2002). Flow. London: Rider.

Davies, W. (2015). The happiness industry: How the Government and big business sold us well-being. London: Verso.

Dawis, R.V. \& Lofquist, L.H. (1984). A psychological theory of work adjustment. Minneapolis: University of Minneapolis Press.

Deci, E. L., \& Ryan, R. M. (2008). Hedonia, eudaimonia, and well-being: An introduction. Journal of Happiness Studies, 9, 1-11. doi: 10.1007/s10902-006-9018-1

Diener, E. (1984). Subjective well-being. Psychological Bulletin, 95, 542-575.

Diener, E. (2003). What Is Positive about Positive Psychology: The Curmudgeon and Pollyanna. Psychological Inquiry, 14, 2, 115-120.

Diener, E., Lucas, R.E., Schimmack, U. \& Helliwell, J.F. (2009). Well-being for public policy. Oxford: Oxford University Press.

Dik, B.J., Duffy, R.D. \& Eldridge, B.M. (2009). Calling and vocation in career counseling: Recommendations for promoting meaningful work. Professional Psychology: Research and Practice, 40, 6, 625-632. doi: 10.1037/a0015547

Dik, B.J., Duffy, R.D., Allan, B.A., O’Donnell, M.B., Shim, Y. \& Steger, M.F. (2015). Purpose and meaning in career development applications. The Counseling Psychologist, 43, 4, 558-585. doi: $10.1177 / 0011000014546872$

Dik, B.J. \& Hansen, J.C. (2008). Following passionate interests to well being. Journal of Career Assessment, 16, 86-100. doi:10.1177/1069072707305773

Duffy, R.D. \& Dik, B.J. (2013). Research on calling: what we have learned and where are we going? Journal of Vocational Behavior, 83, 428-436. doi: 10.1016/j.jvb2013.06.006

Ecclestone, K. \& Hayes, D. (2008). The Dangerous Rise of Therapeutic Education. London: Routledge.

Eggerth, D.E. (2008). From theory of work adjustment to person-environment correspondence counselling: vocational psychology as positive psychology. Journal of Career Assessment, 16, 60-74. doi:10.1177/1069072707305771

Ehrenreich, B. (2009). Smile or die: How positive psychology fooled America and the world. London: Granta.

Erdogan, B., Bauer, T. N., Truxillo, D. M., \& Mansfield, L. R. (2012). Whistle while you work: A review of the life satisfaction literature. Journal of Management, 38, 1038-1083. doi: $10.1177 / 0149206311429379$

Faragher, E. B., Cass, M., \& Cooper, C. L. (2005). The relationship between job satisfaction and health: A meta-analysis. Occupational and Environmental Medicine, 62, 105-112.

doi:10.1136/oem.2002.006734 
Findlay, P., Kalleberg, A.L. \& Warhurst, C. (2013). The challenge of job quality. Human Relations, 66, 4, pp441-451. doi: 10.1177/0018726713481070

Fineman, S. (2006). On being positive: Concerns and counterpoints. Academy of Management Review 31, 2, 270-291.

Fredrickson, B.L. (2005). The broaden-and-build theory of positive emotion. In F.A. Huppert, N. Baylis \& B. Keverne (Eds.) The science of well being (pp.217-241). Oxford: Oxford University Press.

Friedli, L. \& Stearn, R. (2015). Positive affect as coercive strategy: conditionality, activation and the role of psychology in UK government workfare programmes. Medical Humanities, 41:40-47. doi:10.1136/medhum-2014-010622

Garland, E.L., Fredrickson, B., Kring, A.M., Johnson, D.P., Meyer, P.S., Penn, D.L. (2010). Upward spirals of positive emotions counter downward spirals of negativity: Insights from the broaden-andbuild theory and affective neuroscience on the treatment of emotion dysfunctions and deficits in psychopathology. Clinical Psychology Review, 30, 7, 849-864. doi:10.1016/j.cpr.2010.03.002

Graham, H., Howard, K.J. \& Dougall, A.L. (2012). The growth of occupational health psychology. In R.J. Gatchell \& Schultz, I.Z. (Eds.). Handbook of occupational health and wellness (pp. 39-59). USA: Springer.

Grant, A.M. (2016). The contribution of qualitative research to coaching psychology: Counting numbers is not enough, qualitative counts too. Journal of Positive Psychology. [online first]. doi: $10.1080 / 17439760.2016 .1262616$

Grant, A.M. \& Palmer, S. (2015). Integrating positive psychology and coaching psychology into counselling psychology. Counselling Pychology Review, 30, 3, $22-25$.

Haase, C.M., Poulin, M.J. \& Heckhausen, J. (2012). Happiness as a motivator: Positive affect predicts primary goal striving for career and educational goals. Personality and Social Psychology, 38, 1093-1104. doi: 10.1177/0146167212444906

Hackman, J.R. (2009). The perils of positivity. Journal of Organisational Behaviour, 30, 2, 309-320.

Hanisch, K.A. (1999). Job loss and unemployment research from 1994 to 1998: A review and recommendations for research and intervention. Journal of vocational behaviour, 55, 2: 188-220.

Harris, A.H.S., Thoresen, C.E. \& Lopez, S.J. (2007). Integrating positive psychology into counselling: Why and (when appropriate) how. Journal of Counseling and Development, 85,3-13.

Harter, J.K., Schmidt, F.L. \& Keyes, C.L. (2002). Well-being in the workplace and its relationship to business outcomes: a review of the Gallup Studies. In: C.L. Keyes \& J. Haidt (Eds) Flourishing: the positive person and the good life. Washington DC: American Psychological Association.

Hartung, P.J. \& Taber, B.J. (2008). Career construction and subjective well-being. Journal of Career Assessment, 16, $75-85$.

Harzer, C. \& Ruch, W. (2012). When the job is a calling: the role of applying one's signature strengths at work. Journal of Positive Psychology, 7, 362-371. doi: 10.1080/17439760.2012.702784

Held, B.S. (2004). The Negative Side of Positive Psychology. Journal of Humanistic Psychology, 44, 1, pp 9-46. doi:10.1177/0022167803259645.

Henderson, S.J. (2000). "Follow your bliss": A process for career happiness. Journal of Counselling and Development, 78, 305-315. doi: 10.1002/j.1556-6676.2000.tb01912.x 
Hirschi, A. (2011). Callings in career: a typological approach to essential and optional components. Journal of Vocational Behaviour, 79, 60-73. doi: 10.1016/j.jvb.2010.11.002

Holland, J. (1997). Making vocational choices: a theory of vocational personalities and work environments (3rd Edition) Odessa FL: Psychological Assessment Resources.

Hochschild, A.R. (1983). The managed heart: the commercialisation of human feeling. Berkeley: University of California Press.

Isen, A.M. \& Erez, A. (2009). Some measurement issues in the study of affect. In A.D. Ong \& M.H.M. van Dulmen (eds.) Oxford handbook of methods in positive psychology. Oxford: Oxford University Press. pp. 250-265.

Ivtzan, I., Lomas, T., Hefferon, K., \& Worth, P. (2015). Second wave positive psychology: Embracing the dark side of life. Routledge.

Jacobsen, M. (2010). Positive psychology for career counsellors, Career Planning and Adult Development, 26, 1, 26-39.

Jefferson, T. (1776) The United States declaration of independence. Washington: Library of Congress.

Joseph, S. (2015). Positive therapy: Building bridges between positive psychology and person centred psychotherapy.(2 ${ }^{\text {nd }}$ Edition). Hove: Routledge.

Juntunen, C.L. \& Wettersten, K.B. (2006). Work hope: development and initial validation of a measure. Journal of Counselling Psychology, 53, 1, 94-106.

Kellett, Purdie, Bickerstaffe, Hopper, \& Scott. (2013). Predicting return to work from health related welfare following low intensity cognitive behaviour therapy. Behaviour Research and Therapy, 51, 3, 134-141. doi: 10.1016/j.brat.2012.12.002

Kidd, J.M. (1998). Emotion: an absent presence in career theory. Journal of vocational behavior, 52, 3: $275-288$.

Klimka, M. \& Budzińska, G. (2015). Being positive. Approaching career design from the perspective of positive psychology. Journal of Education Culture and Society, 1, 89-100. doi: 10.15503/jecs20151.89.100

Krumboltz, J.D. (1996). A learning theory of career counselling. In M.L. Savickas \& W.B. Walsh (Eds.) Handbook of career counselling theory and practice (pp.55-80). Palo Alto, CA: Davies-Black.

Layard, R. (2005). Happiness: Lessons from a new science. London: Penguin.

Lazarus, R.S. (2003). Does the positive psychology movement have legs? Psychological enquiry, 14, 2: 93-109.

Linley, P.A. \& Harrington, S. (2006). Playing to your strengths. The Psychologist, 19, 86-89.

Linley, P.A. \& Harrington, S. (2007). Integrating positive psychology and coaching psychology: shared assumptions and aspirations? In S.Palmer \& A.Whybrow (Eds.) Handbook of coaching psychology: A guide for practitioners (pp. 40 -56). Hove: Routledge.

Linley, P.A., Harrington, S. \& Garcea, N. (2010). Finding the positive in the world of work. In P.A Linley, S.Harrington \& N. Garcea (eds) Oxford Handbook of Positive Psychology and Work. Oxford: Oxford University Press. 
Littman-Ovadia, H., \& Davidovitch, N. (2010). Effects of congruence and character-strength deployment on work adjustment and well-being. International Journal of Business and Social Science, 1, 3, 137- 145.

Littman-Ovadia, H. \& Lavy, S.(2016). Going the extra mile: Perseverance as a key strength at work. Journal of Career Assessment, 24, 2, 240-252. doi: 10.1177/1069072715580322

Littman-Ovadia, H., Lazar-Butbul, V. \& Benjamin, B.A. (2014). Strengths based career counselling: Overview and initial evaluation. Journal of Career Assessment, 22, 3, 403-419. doi: $10.1177 / 1069072713498483$

Lomas, T. (2016). Positive psychology - the second wave. The Psychologist, 29, 7: 536-539.

Lopez, S.J., Snyder, C.R. \& Rasmussen. H.N. (2003). Striking a vital balance: developing a complementary focus on human weakness and strength through positive psychological assessment. In S.J. Lopez \& C.R. Snyder (Eds) Positive psychological assessment: a handbook of models and measures (pp.3-20). Washington: American Psychological Association.

Lyubomirsky, S., King, L., \& Diener, E. (2005). The benefits of frequent positive affect: Does happiness lead to success? Psychological Bulletin, 131, 803-855. doi: 10.1037/0033-2909.131.6.803

Maggiori, C., Johnston, C.S., Krings, F., Massoudi, K. \& Rossier, J. (2013) The role of career adaptability and work conditions on general and professional well-being. Journal of Vocational Behavior, 83, 437-449. doi: 10.1016/j.jvb.2013.07.001

Magyar-Moe, J.L., Owens, R.L. \& Scheel, M.J. (2015). Applications of positive psychology n counselling psychology: Current status and future directions. The Counseling Psychologist, 43, 4, 494-507. doi: 10.1177/0011000015581001

Magyar-Moe, J.L., Owens, R.L. \& Conoley, C.W. (2015). Positive psychology interventions in counselling: What every counselling psychologist should know. The Counseling Psychologist, 43, 4, 508-557. doi: 10.1177/0011000015573776

Maslow, A. (1970). Motivation and personality. ( $2^{\text {nd }}$ edition). New York: Harper \& Row.

McCash, P. (2006). We are all career researchers now: breaking open career education and DOTS. British Journal of Guidance and Counselling, 34, 429-449. doi: 10.1080/03069880600942558

McGregor, I., McAdams, D.P. \& Little, B.R. (2006). Personal projects, life stories, and happiness: On being true to traits, Journal of Research in Personality, 40, 551-572 . doi:10.1016/j.jrp.2005.05.002

Mitchell, K.E., Levin, S.A. \& Krumboltz, J.D. (1999). Planned Happenstance: Constructing Unexpected Career Opportunities. Journal of Counseling and Development, 77, 2, 115-124. doi: 10.1002/j.1556-6676.1999.tb02431.x

Mills, M.J., Fleck, R. \& Kozikowski, A. (2013). Positive psychology at work: A conceptual review, state-of-practice assessment, and a look ahead. Journal of Positive Psychology, 8, 153-164. doi: 10.1080/17439760.2013.776622

Mongrain, M. \& Anselmo-Matthews, T. (2012). Do positive psychology exercises work? A replication of Seligman et al. (2005) Journal of Clinical Psychology, 68, 4, 382-389. doi: $10.1002 /$ jclp. 21839

Nettle, D. (2006). Happiness: The science behind your smile. Oxford: Oxford University Press. 
Norem, J.K. \& Chang, E.C. (2002). The positive psychology of negative thinking, Journal of Clinical Psychology, 58, 9, 993-1001. doi: 10.1002/jclp.10094

Ng, T. W., Eby, L. T., Sorensen, K. L., \& Feldman, D. C. (2005). Predictors of objective and subjective career success: A meta-analysis. Personnel Psychology, 58, 2, 367-408

Owens, R.L., Moti, T.C. \& Krieshok, T.S. (2016). A comparison of strengths and interests protocols in career assessment and counselling. Journal of Career Assessment, 24, 4, 605-622. doi: $10.1177 / 1069072715615854$

Park, N. \& Peterson, C. (2007). Methodological issues in positive psychology and the assessment of character strengths. In: A.D. Ong \& M.H.M. van Dulmen (Eds) Oxford handbook of methods in positive psychology. Oxford: Oxford University Press, pp292-305.

Peng, H. (2015). Infusing positive psychology with spirituality in a strength-based group career counselling to evaluate college students' state anxiety. International Journal of Psychological Studies, 7, 1, pp.75-84. doi: 10.5539/ijps.v7n1p75

Peterson, C. (2009). Foreword. In S.J. Lopez \& C.R. Snyder (Eds.) Oxford handbook of positive psychology ( $2^{\text {nd }}$ edition). Oxford: Oxford University Press. pp. xxiii-xxiv.

Peterson, C. \& Seligman, M.E.P. (2004). Character strengths and virtues: A handbook and classification. Values in Action Institute. Oxford: Oxford University Press/American Psychological Association.

Poole, M.E., Langan-Fox, J. \& Omodie, M. (1993). Contrasting subjective and objective criteria as determinants of perceived career success: a longitudinal study. Journal of Occupational and Organisational psychology, 66, 39-54.

Power, M. (2016). Understanding happiness: a critical review of positive psychology. London: Routledge

Preskill, H. \& Donaldson, S.I. (2008) Improving the evidence base for career development programs: making use of the evaluation profession and positive psychology movement. Advances in Developing Human Resources, 10, 1. doi: 10.1177/1523422307310117

Proudfoot, J., Guest, D., Carson, J., Dunn, G. \& Gray, J. (1997). Effect of cognitive-behavioural training on job-finding among long-term unemployed people. The Lancet, 350, 96-100.

Rath, T. \& Harter, J. (2010). Wellbeing: The five essential elements. New York: Gallup Press.

Robertson, P.J. (2013). The well-being outcomes of career guidance. British Journal of Guidance and Counselling, 41, 254-266. doi: 10.1080/03069885.2013.773959

Robertson, P.J. (2015). Positive psychology: a movement to reintegrate career counselling within counselling psychology? Counselling Psychology Review, 30, 3, 26-35.

Robitscheck, C. \& Woodson, S.J. (2006). The Counseling Psychologist, 34, 2, 260-275. doi: $10.1177 / 0011000005281321$

Rodger, A. (1952). The seven point plan. London: National Institute for Industrial Psychology.

Rottinghaus, P.J., Day, S.X. \& Borgen, F.H. (2005). The career futures inventory: A measure of career related adaptability and optimism. Journal of Career Assessment, 13, 1, 3-24. doi: $10.1177 / 1069072704270271$ 
Ryan, R.M., Huta, V.A. \& Deci, E.L. (2008). Living well: a self-determination theory perspective on eudaimonia. Journal of Happiness Studies, 9, 139-170.

Ryff, C. D., \& Singer, B. H. (2008). Know thyself and become what you are: A eudaimonic approach to psychological well-being. Journal of Happiness Studies, 9, 13-39.

doi: 10.1007/s10902-006-9019-0

Savickas, M.L. (2008). Toward a taxonomy of human strengths: career counseling's contribution to positive psychology. In W.B. Walsh (Ed) Counseling psychology and optimal human functioning (pp.229-250). Mahwah, NJ: Lawrence Erlbaum.

Savickas, M.L. \& Spokane, A.R. (1999). Introduction: reconsidering the nature, measurement and uses of vocational interests. In M.L. Savickas \& A.R. Spokane (Eds.) Vocational interests: Meaning, measurement and counseling use. Palo Alto CA: Davies-Black Publishing.

Schnell, T., Höge, T. \& Pollett, E. (2013). Predicting meaning in work: Theory, data, implications. Journal of Positive Psychology, 8, 6, 543-554. doi: 10.1080/17439760.2013.830763

Schneider, K. (2011). Toward a Humanistic Positive Psychology. Existential Analysis: Journal of the Society for Existential Analysis, 22, 1, pp. 32-38.

Seligman, M.E.P. (2002). Authentic happiness. New York: Free Press.

Seligman, M.E.P. \& Csikszentmihalyi, M. (2000). Positive psychology: an introduction. American Psychologist, 55, 5-14. doi: 10.1037/0003-066X.55.1.5

Seligman, M.E.P., Steen, T.A., Park, N. \& Peterson, C. (2005). Positive psychology progress: Empirical validation of interventions. American Psychologist, 60, 410-421.

Sen, A. K. (1987). On Ethics \& Economics. Oxford: Basil Blackwell.

Shackelton, J. (2012). Wellbeing at work: any lessons? In: P. Booth (Ed)...And the pursuit of happiness: wellbeing and the role of government, pp131- 159. London: The Institute of Economic Affairs.

Sheldon, K.M. \& Lyubomirsky, S. (2006). Achieving sustainable happiness: change your actions, not your circumstances. Journal of happiness studies, 7, 1: 55-86.

Silvia, P. (2006). Exploring the psychology of interest. Oxford: Oxford University Press.

Snyder, C.R., Lopez, S.J., Edwards, L.M., Pedrotti, J.T., Prosser, E.C., Walton, S.L., Spalitto, S.V. \& Ulven, J.C. (2003). Measuring and labelling the positive and the negative. In S.J. Lopez \& C.R.

Snyder (Eds) Positive psychological assessment: a handbook of models and measures (pp. 21-40).

Washington: American Psychological Association.

Steffen, E., Vossier, A. \& Joseph, S. (2015). From shared roots to fruitful collaboration: How counselling psychology can benefit from (re)connecting with positive psychology. Counselling Psychology Review, 30, 3, 1-11.

Steger, M.F. \& Dik, B.J. (2009). If one is looking for meaning in life, does it help to find meaning in work? Applied Psychology: Health and Well-being, 1, 303-320.

doi:10. Ill 1/j. I 758-0854.2009.01018.x

Steger, M. F. \& Dik, B.J. (2010). Work as meaning: Individual and organizational benefits of engaging in meaningful work. In P.A. Linley, S. Harrington \& N. Garcea (Eds) Oxford handbook of positive psychology and work. pp. 131-142. Oxford: Oxford University Press. 
Steger, M.F., Dik, B.J. \& Duffy, R.D. (2012). Measuring Meaningful Work: The Work and Meaning Inventory (WAMI). Journal of Career Assessment, 20, 3, 322-337. doi: 1069072711436160

Straume, L.V. \& Vitters $\varnothing$, J. (2012). Happiness, inspiration and the fully function person: separating hedonic and eudaimonic well-being in the workplace. Journal of Positive Psychology, 7, 387-398. doi: 10.1080/17439760.2012.711348

Taveira, M.C. \& Moreno, M.L.R. (2003). Guidance theory and practice: the status of career exploration. British Journal of Guidance and Counselling, 31, 189-208. doi: 10.1080/0306988031000102360

Van Deurzen, E. (2009). Psychotherapy and the quest for happiness. London: Sage.

Waddell, G., \& Burton, A. K. (2006). Is work good for your health and well-being? London: Department for Work and Pensions.

Warr, P. B. (2007). Work, happiness and unhappiness. Mahwah, NJ: Erlbaum.

Warren, S. (2010). What's wrong with being positive? In P.A. Linley, S. Harrington \& N. Garcea (Eds) Oxford handbook of positive psychology and work. pp. 313-322. Oxford: Oxford University Press.

Wrzesniewski, A. (2003). Finding positive meaning at work. In K.S. Cameron, J.E. Dutton \& R.E. Quinn (Eds) Positive organizational scholarship (pp.296-308) San Francisco: Barrett-Koehler.

Wrzesniewski, A. (2012). Callings. In K.S. Cameron \& G.M. Spreitzer (Eds) The Oxford handbook of positive organizational scholarship. pp.45-55. Oxford: Oxford University Press.

Yates, J. (2013a). A positive approach to career coaching. Journal of the National Institute for Career Education and Counselling, 30,46-53.

Yates, J. (2013b). Handbook of career coaching. Hove: Routledge.

Zikic, J. \& Franklin, M. (2010). Enriching careers and lives: introducing a positive, holistic and narrative career counselling method that bridges theory and practice. Journal of Employment Counseling, 47, 180-189. 